\title{
TEMPORAL AND SPATIAL VARIABILITY OF THE DIAMETER DISTRIBUTION IN A SECONDARY BRAZILIAN ATLANTIC FOREST SUGGESTS SITE-SPECIFIC MANAGEMENT PRACTICES
}

\author{
Jônio Pizzol Caliman ${ }^{*} \odot$, Geraldo Gonçalves dos Reis ${ }^{3} \odot$, Maria das Graças Ferreira Reis ${ }^{3} \odot$, He- \\ lio Garcia Leite ${ }^{3} \odot$,Carlos Moreira Miquelino Eleto Torres ${ }^{3} \odot$, Margarete Marin Lordelo Volpato ${ }^{4}$ ( ) , \\ Rafael Tassinari Resende ${ }^{5}$ and Marco Antonio Monte ${ }^{6}{ }^{\circ}$
}

\footnotetext{
${ }^{1}$ Received on 14.08.2019 accepted for publication on 05.03.2020.

${ }^{2}$ Universidade Federal de Viçosa, Programa de Pós-Graduação em Ciência Florestal, Viçosa , MG-Brasil. E-mail: <jpcaliman@gmail. com>.

${ }^{3}$ Universidade Federal de Viçosa, Departamento de Engenharia Florestal, Viçosa , MG-Brasil E-mail: <greis@ufv.br>,<mgfreis@ufv. br>,<hgleite@gmail.com> and <carlos.eleto@ufv.br>.

${ }^{4}$ Empresa de Pesquisa Agropecuária de Minas Gerais, Lavras, MG-Brasil. E-mail: <margarete@epamig.ufla.br>

${ }_{5}^{5}$ Empresa Brasileira de Pesquisa Agropecuária Recursos Genéticos e Biotecnologia, Brasilia, DF-Brasil. E-mail: <rafael.tassinari@gmail. com>.

${ }^{6}$ Universidade Federal Rural do Rio de Janeiro, Departamento de Silvicultura, Seropédica, RJ-Brasil. E-mail: <marcomonte.ufrrj@gmail.com>. *Corresponding author.
}

\begin{abstract}
The diameter distribution of a forest makes it possible to understand its ecological processes and to define actions related to forest management aiming at forest conservation, biodiversity increase, production, and carbon sequestration, among others. This study aimed to identify variation in the diameter distribution in a secondary Atlantic Forest, as a function of sites, over 24 years. The diameter at $1.3 \mathrm{~m}$ in height $(d b h)$ was measured for each tree over $5.0 \mathrm{~cm} d b h$, in ten sites, from 1992 to 2016 . It was analyzed the quadratic mean diameter $(D q)$, the $D q$ annual periodic increment $\left(A P I_{D q}\right)$, the Liocourt's Quotient $(q)$, and the diameter distribution with Meyer's exponential model. The average $A P I_{D q}$ over 24 years was $0.03 \mathrm{~cm}$ year ${ }^{-1}$, an average increase of $0.21 \%$, with site variation ranging from $0.74 \%$ to $-0.45 \%$. The diameter distribution of the forest as a whole maintained the reverse J-shaped over 24-years. When the sites in each inventory year were analyzed, the variation in the diameter distribution was evident, and there were differences in the recovery capacity of the reverse J-shaped distribution from 1992 to 2016. The overall results indicate that, whenever possible, the management plan to recover the structure of the Atlantic Forest remnants should be site-specific, particularly in the mountainous region where the environmental conditions are quite diverse.
\end{abstract}

Keywords: Uneven-aged forest, Diameter structure dynamic, Secondary succession.

\section{VARIABILIDADE TEMPORAL E ESPACIAL DA DISTRIBUIÇÃO DE DIÂMETRO EM UMA MATA ATLÂNTICA SECUNDÁRIA SUGERE PRÁTICAS DE MANEJO ESPECÍFICAS DO LOCAL}

\begin{abstract}
RESUMO - A distribuição de diâmetros de uma floresta permite entender seus processos ecológicos e definir ações relacionadas ao manejo florestal visando a conservação da floresta, aumento da biodiversidade, produção e sequestro de carbono, entre outros. Este estudo buscou identificar variações na distribuição diamétrica em uma Mata Atlântica secundária, em função de sítios, ao longo de 24 anos. O diâmetro a 1,3 m de altura (dap) foi medido para cada árvore acima de 5,0 cm dap, em dez locais, de 1992 a 2016. Foi analisado o diâmetro médio quadrático $(D q)$, o incremento periódico anual em $D q\left(I P A_{D q}\right)$, o Quociente de Liocourt $(q)$ e a distribuição de diâmetros com o modelo exponencial de Meyer. O IPA $A_{D q}$ médio em 24 anos foi de $0,03 \mathrm{~cm}^{-1}$ ano um aumento médio de $0,21 \%$, com variação local de $0,74 \%$ a $-0,45 \%$. A distribuição de diâmetros da floresta como um todo manteve o formato de J-invertido ao longo de 24 anos. Quando os locais foram analisados em cada ano de inventário, a variação da distribuição de diâmetros foi evidente e houve diferenças na capacidade de recuperação
\end{abstract}

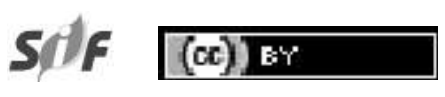

Revista Árvore 2020;44:e4406 http://dx.doi.org/10.1590/1806-908820200000006 
da distribuição para a forma de J-invertido de 1992 a 2016. Os resultados indicam que, sempre que possível, o plano de manejo para recuperar a estrutura dos remanescentes da Mata Atlântica deve ser específica para cada local, particularmente na região montanhosa, onde as condições ambientais são bastante diversas.

Palavras-Chave: Floresta inequiânea, Dinâmica da estrutura diamétrica, Sucessão secundária.

\section{INTRODUCTION}

The Brazilian Atlantic Forest, even highly fragmented and degraded (SOSMA, 2016; ArroyoRodríguez et al., 2017), supports high biodiversity with many commercially valuable species, and has a high potential for carbon sequestration, as most fragments are in regeneration processes (Vieira et al., 2011; Torres et al., 2013; Souza, 2015). To understand the forest structure, the dynamics and the growth of the trees (such as the tree diameter distribution), which helps defining management plans to favour forest regeneration, a continuous forest inventory (CFI) is required (Campos and Leite, 2017; Souza and Soares, 2013).

The diameter distribution can vary with site characteristics, such as aspect, slope, radiation, soil moisture, fertility (Felfili, 1997; Imaña-Encinas et al., 2013; Orellana et al., 2014; Lima et al., 2015; Lima et al., 2017), and with forest management techniques (Vasconcelos et al., 2009). This information is important for the establishment of management plans for the even and uneven-aged forests, explaining age structure, regeneration strategies, wood harvesting methods, and others (Smith and Lamson, 1982; Campos et al., 1983; Campos and Leite, 2013; Souza and Soares, 2013). Also, it allows forest managers to relate it to the stand density, volume, prognosis of yield, vegetation diversity, and forest disturbances (Schreuder and Swank, 1974; Denslow, 1995).

In the undisturbed uneven-aged forest, there is a decreasing number of trees in successive diameter classes (Meyer, 1952), distinguished by its exponential form (reverse J-shaped), and an adequate number of trees compensate for the natural mortality, and for the harvested trees. The probability density or cumulative diameter distribution functions helps in describing the tropical forest diameter structure for a specific age (Umaña and Alencar, 1998; Imaña-Encinas et al., 2013; Orellana et al., 2014; Souza et al., 2016; Lima et al., 2015; Lima et al., 2017), or for an age sequence (Felfili et al., 1997; Canalez et al., 2006; Vasconcelos et al., 2009; Machado et al., 2017; Reis et al., 2018).
Variation in diameter structure among sites also plays a vital role in the decision-making with respect to forest management, focusing mainly on maintaining the wood production and biodiversity (Meyer, 1952; Ige et al., 2013; Lima et al., 2017).

The question to be answered in this study is: the diameter distribution should be analysed without any consideration of its variation over time and among sites, if there are different successional stages, or physiographic, edaphic and microclimatic conditions, within the forest fragment? In this context, the objective of this study was to analyze the spatial differences and, the temporal evolution of the diameter distribution of a secondary Atlantic Forest over 24 years, considering the forest as a whole, and different sites within the forest.

\section{MATERIAL AND METHODS}

The study was performed in a secondary forest area, classified as Mountain Semideciduous Seasonal Forest, in the domain of the Atlantic Forest, in Viçosa, Minas Gerais, Brazil (20 48' 00" S latitude and $42^{\circ} 51^{\prime}$ $30^{\prime \prime} \mathrm{W}$ longitude; altitude of $782 \mathrm{~m}$ ). This is the largest forest fragment in the region, extending over 194 ha. This area experienced different levels of disturbances in the past, chiefly for selective wood logging and partial tree removal to accommodate the coffee crop (Coffea arabica L.) beneath the forest, and for pasture cultivation; however, it has gone through full protection lately (Garcia et al., 2011). The matrix of the neighboring areas includes forests in various stages of succession and pasture. The relief consists of a sequence of depressed plateaus, irregular surfaces, and the coincidence of the elevation tops, with a prevalence of Red-Yellow Latosol along the slopes and top, and Red Yellow Cambic Podzols on the terraces (Garcia et al., 2011). The climate is humid subtropical (Cwa); the average annual temperature is $19.5^{\circ} \mathrm{C}$ and the average annual rainfall is $1,361 \mathrm{~mm}$; there is a period with water deficit during the winter.

Trees diameter data was obtained in 1992, 1995, 1998, 2001, 2004, 2007, 2012 and 2016, in ten sites (L1,

Revista Árvore 2020;44:e4406 
..., L10), with distinct features (topographic position, aspect, soil fertility and successional stages) within the studied area, as described in Silva et al. (2004) and Caliman (2019). The inventory was undertaken in 60 permanent plots (six contiguous $10 \times 20 \mathrm{~m}$ rectangular plots in each site). Tree diameter at $1.3 \mathrm{~m}$ of height $(\mathrm{dbh})$ of all the individual trees of $\mathrm{dbh} \geq 5.0 \mathrm{~cm}$ was measured for each inventory year, with identification at the family, genus and species levels, when possible, according to the Angiosperm Phylogeny Group System (APG III, 2009). Data from these adult trees inventories, mainly related to the species importance value, were, partially, published by Fernandes (1998), Silva (2003), Silva et al., (2004), Caliman (2015) and Souza (2015).

The quadratic mean diameter $(D q)$ was used as it is a variable that consider the diameter variance (Campos and Leite, 2017), i.e., $D q^{2}=\left(d b h^{2}\right)+S_{d b h}^{2}$, and it was obtained by the expression:

$D q=\sqrt{n^{-1} \sum_{i=1}^{n} d b h_{i}^{2}}$

where $n=$ number of individuals, and $d b h=$ diameter at $1.3 \mathrm{~m}$ of height, $\mathrm{cm}$.

The annual periodic increment of $D q\left(A P I_{D q}\right)$ for each sampling period was obtained by the expressions:

$A P I_{D q}(\mathrm{~cm})=\frac{\left(D q_{j+1}-D q_{j}\right)}{t}$ and $A P I_{D q}(\%)=100 \frac{A P I_{D q}}{D q_{j}}$,
where $A P I^{t}=$ annual periodic increment, in $\mathrm{cm}$ year ${ }^{-1}$ and percentage; $D q=$ value of quadratic mean diameter obtained in two successive inventory years $(j$; $j+1)$ and $t=$ period, in years, between $j$ and $j+1$ ).

The trees were grouped into diameter classes, starting at the class center of $7.5 \mathrm{~cm}$, with an amplitude of $5.0 \mathrm{~cm}$. The diameter distributions were compared in three ways: (1) whole forest fragment investigated for each inventory year, without evaluating the different sites; (2) each inventory year, considering the variations in the sites; and (3) each forest site, considering the inventory years. The probabilities of the occurrence of the individuals in each diameter class was calculated by Meyer's exponential function: $p_{i}=\beta_{0} e^{\beta 1 X i}+\varepsilon_{\mathrm{i}}$, where: $p_{i}$ $=$ proportion of individuals in the $i$-th diameter class, $X_{i}$ $=i$-th center of the diameter class and, $\beta_{0}, \beta_{1}=$ model parameters, $\varepsilon_{i}=$ error. The choice of Meyer's exponential function is justified to obtain the Liocourt's Quotient, widely used in forest management to reach a balanced forest with the application of the $\mathrm{BDq}$ method, for example (Meyer, 1952; Campos et al., 1983). With the Liocourt's Quotient, there is also the possibility of inferring on the conservation status of the uneven-aged forests, the proportionality of the number of individuals in the diameter classes and the shape and intensity of the projected curve (Alves Junior et al., 2010).

The adherence between the observed and estimated distributions was evaluated using the KolmogorovSmirnov test $(\alpha=0.05)$. The model fit was evaluated with the Pearson correlation coefficient between observed and estimated frequency (r). Liocourt's Quotient $(q)$ was estimated with $q=\frac{\hat{p_{i}}}{\hat{p}_{i+1}}$. Besides that, $q$ quotients were also calculated for the observed diameter distribution by dividing the number of trees in each $d b h$ class by the number of trees in the next larger $d b h$ class (Meyer, 1952), and the average of these quotients was termed $q$-value. The number of individuals per hectare $\left(n_{i}\right)$, in each diameter class, were calculated by $p_{i}{ }^{*} N_{o b s}$, where Nobs is the total number of individuals per hectare.

The adjusted diameters distribution were compared among the inventory years and sites, using the statistic procedure by Leite and Oliveira (2002), with 5\% of significance. This procedure resulted from a combination of the statistic $F$, the test of the relative medium error and, the linear correlation coefficient between two analytical methods or any two vectors. Based on these data, a ruling decision was proposed to test the hypothesis of identity between two analytical methods or any two vectors, that is, groups of quantitative data. The diameters distribution were compared between the inventory years and between sites using an identity test (Leite and Oliveira, 2002; Regazzi, 2003), taking into consideration $Y_{j i}$ as a $j$-th observation of variable $Y$, in the dataset $i$, with $i=1,2, \ldots, H$ and, $j=1,2, \ldots, n_{i}$, being $n=\sum_{i}^{H}=1 n_{i}$ and, $K_{1}$ and $K_{2}$ being the number of coefficients in a complete model and a reduced model, respectively, for hypothesis H0 (identity hypothesis). Then, under normality:

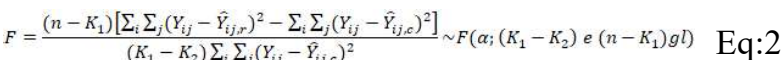

$\hat{Y}_{i j, r}$ is the $j$-th estimated observation of variable $Y$ of a reduced model and $\hat{Y}_{i j, c}$ is the $j$-th estimated observation of variable $Y$ of a complete model. As the comparisons of the equations of the exponential model were made 2 by 2 , it was considered that, $H=2, K_{1}=4$ (four coefficients) and $K_{2}=2$ (two coefficients). The R software (R CORE TEAM, 2017) was used to perform the analysis with the packages nlme, systemfit, ggplot2, reshape2, and Metrics.

Revista Árvore 2020;44:e4406 


\section{RESULTS}

Diameter growth varied with the inventory year and site (Table 1). On average, the $A P I$ of the quadratic mean diameter $(D q)$ in the forest being investigated was $0.03 \mathrm{~cm}^{\text {year }}{ }^{-1}$, representing a $0.21 \%$ increase; the highest APIs were recorded at sites L03 to L07 (0.06 to $0.09 \mathrm{~cm} \mathrm{year}^{-1}$ ), equivalent to $0.74 \%, 0.46 \%, 0.39 \%$, $0.54 \%$ and $0.59 \%$ per year, respectively. However, the $D q$ in the other sites showed a growth decline, as evident in the sites L01 $\left(-0.07 \mathrm{~cm}_{\text {year }}{ }^{-1},-0.45 \%\right)$, L08 $(-0.05 \mathrm{~cm}$ year $\left.^{-1},-0.35 \%\right)$ and L09 (-0.02 cm year $\left.{ }^{-1},-0.08 \%\right)$. The $\mathrm{Dq}$ also revealed growth oscillations as a function of inventory intervals, with $0.79 \%$ and $0.64 \%$ increase per year, respectively, during the 1995-1998 and 2012-2016 inventory intervals; the lowest $A P I$ values were observed during the 1998-2001 (0.07\% per year) and 2004-2007 $(0.12 \%$ per year) inventory intervals. On the analysis of all the inventory intervals and sites, the most significant changes in the trees $D q$ occurred at the sites L02, from 1992 to 1995 (-3.31\% per year) and L07, from 2001 to 2004 (2.67\% per year).

The estimated diameter distribution for the forest as a whole for the different inventory years was faithful to the observed distribution, depending upon the significance $(p \geq 0.5590)$ attained by the KolmogorovSmirnov (K-S) test; a high correlation was evident between the estimated and observed values $(\mathrm{r}>0.998)$. The $\beta_{0}$ and $\beta_{1}$ parameters of Meyer's exponential model showed similarity to each other, both in the inventory years, as well as the $q$ and $q$-value ( 2.20 to 2.43 and 1.89 to 2.89 , respectively), suggesting a similarity in the diameter distribution between the inventory years. The equations were: $p_{i 1992}=1.7599 e^{-0.1576 X_{i} ;} p_{i 1995}=2.0374 e^{-0.1718 X_{i} ;}$; $p_{i 1998}=2.0121 e^{-0.1711 X_{i}} ; p_{i 2001}=2.0445 e^{-0.1728 X_{i} ;} p_{i 2004}=2.1148 e^{-0.1768 X_{i}} ;$ $p_{i 2007}=2.0666 e^{-0.1748 x_{i} ;} p_{i 2012}=2.1158 e^{-0.1771 X_{i}} ; p_{i 2016}=2.1216 e^{-0.1778 x_{i}}$. The total number of tree individuals in the forest scale up from 1,613 (1992) to 1,875 individuals ha-1 (2016). Diameter distribution showed a negative exponential form (reverse J-shaped) for all the measurement years, with greater variations in the number of individuals of the first diameter class (Figure 1). Individuals greater than $62.5 \mathrm{~cm}$ diameter class were excluded from Figure 1: one individual of Pseudobombax longiflorum (Mart.) A. Robyns from the $92.5 \mathrm{~cm}$ diameter class in 1992 , which remained in the class of $97.5 \mathrm{~cm}$ from 1995 to 2004, and moved up to the $102.5 \mathrm{~cm}$ class in 2007; one individual of Hieronyma alchorneoides Allemão, that reached the $67.5 \mathrm{~cm} d b h$ class in 2012, and, one individual of Piptadenia gonoacantha (Mart.) J. F. Macbr. which reached the class of $67.5 \mathrm{~cm}$ in 2016.

The sites, in a variety of ways, influenced diameter growth. From the results of the K-S test, the estimated diameter distribution of the sites L01, L08, and L10

Table 1 - Annual periodic increment ( $A P I)$ of the quadratic mean diameter $(D q)$, for each site (L01 to L10) and inventory intervals (1992 to 2016), in a southeast secondary Atlantic Forest, in Minas Gerais, Brazil

Tabela 1 - Incremento periódico anual (IPA) do diâmetro médio quadrático (Dq), para cada local (L01 a L10) e intervalos de inventário (1992 a 2016), em uma Mata Atlântica secundária do sudeste, em Minas Gerais, Brasil

\begin{tabular}{|c|c|c|c|c|c|c|c|c|c|c|c|}
\hline \multirow[t]{2}{*}{ Interval } & \multicolumn{11}{|c|}{ Sites } \\
\hline & L01 & $\mathrm{L} 02$ & L03 & L04 & L05 & L06 & L07 & L08 & L09 & $\mathrm{L} 10$ & Mean \\
\hline \multirow[t]{2}{*}{$1992-1995$} & $-0.33^{1}$ & -0.51 & 0.20 & 0.08 & 0.17 & 0.04 & -0.10 & -0.34 & -0.47 & -0.04 & -0.07 \\
\hline & $(-2.16)^{2}$ & $(-3.31)$ & (1.72) & $(0.65)$ & (1.18) & $(0.28)$ & $(-0.70)$ & $(-2.34)$ & $(-3.08)$ & $(-0.34)$ & $(-0.54)$ \\
\hline \multirow[t]{2}{*}{$1995-1998$} & -0.05 & 0.02 & 0.17 & 0.26 & 0.16 & 0.09 & 0.16 & -0.05 & 0.16 & 0.05 & 0.11 \\
\hline & $(-0.38)$ & $(0.13)$ & (1.44) & (2.04) & $(1.05)$ & $(0.58)$ & (1.13) & $(-0.40)$ & $(1.23)$ & $(0.46)$ & $(0.79)$ \\
\hline \multirow[t]{2}{*}{$1998-2001$} & -0.02 & 0.17 & -0.11 & 0.02 & 0.01 & 0.02 & -0.13 & 0.06 & 0.10 & -0.05 & 0.01 \\
\hline & $(-0.14)$ & $(1.26)$ & $(-0.86)$ & $(0.12)$ & $(0.6)$ & $(0.11)$ & $(-0.98)$ & $(0.47)$ & $(0.77)$ & $(-0.44)$ & $(0.07)$ \\
\hline \multirow[t]{2}{*}{$2001-2004$} & -0.17 & 0.03 & -0.01 & 0.10 & -0.06 & 0.33 & 0.37 & -0.10 & 0.08 & 0.05 & 0.07 \\
\hline & $(-1.22)$ & $(0.22)$ & $(-0.09)$ & $(0.75)$ & $(-0.39)$ & $(2.22)$ & $(2.67)$ & $(-0.78)$ & $(0.62)$ & $(0.45)$ & $(0.53)$ \\
\hline \multirow[t]{2}{*}{$2004-2007$} & -0.03 & 0.00 & 0.19 & 0.07 & -0.06 & -0.08 & 0.11 & 0.00 & -0.03 & 0.11 & 0.02 \\
\hline & $(-0.23)$ & $(0.02)$ & (1.57) & $(0.49)$ & $(-0.36)$ & $(-0.49)$ & $(0.71)$ & $(0.01)$ & $(-0.20)$ & $(0.98)$ & $(0.12)$ \\
\hline \multirow[t]{2}{*}{$2007-2012$} & 0.14 & 0.16 & 0.09 & -0.14 & 0.06 & 0.04 & 0.06 & -0.05 & -0.06 & 0.00 & 0.03 \\
\hline & (1.02) & (1.11) & $(0.72)$ & $(-0.95)$ & (0.39) & $(0.27)$ & $(0.39)$ & $(-0.36)$ & $(-0.42)$ & $(0.00)$ & $(0.24)$ \\
\hline $2012-2016$ & $\begin{array}{c}-0.01 \\
(-0.07)\end{array}$ & $\begin{array}{c}0.26 \\
(1.70)\end{array}$ & $\begin{array}{c}0.09 \\
(0.66)\end{array}$ & $\begin{array}{c}0.01 \\
(0.11)\end{array}$ & $\begin{array}{c}0.12 \\
(0.81)\end{array}$ & $\begin{array}{c}0.13 \\
(0.79)\end{array}$ & $\begin{array}{c}0.14 \\
(0.89)\end{array}$ & $\begin{array}{c}0.12 \\
(0.94)\end{array}$ & $\begin{array}{c}0.07 \\
(0.52)\end{array}$ & $\begin{array}{c}-0.01 \\
(-0.06)\end{array}$ & $\begin{array}{c}0.09 \\
(0.64)\end{array}$ \\
\hline \multirow[t]{2}{*}{ Mean } & -0.07 & 0.02 & 0.09 & 0.06 & 0.06 & 0.08 & 0.08 & -0.05 & -0.02 & 0.02 & 0.03 \\
\hline & $(-0.45)$ & $(0.16)$ & $(0.74)$ & $(0.46)$ & $(0.39)$ & $(0.54)$ & $(0.59)$ & $(-0.35)$ & $(-0.08)$ & $(0.15)$ & $(0.21)$ \\
\hline
\end{tabular}

$1=\mathrm{cm}$ year- ${ }^{1} ;^{2}=$ percentage $\left(\%\right.$ year $\left.{ }^{-1}\right)$

${ }^{1}=\mathrm{cm}$ ano- ${ }^{-1} ;{ }^{2}=$ porcentagem $\left(\%\right.$ ano $\left.^{-1}\right)$

Revista Árvore 2020;44:e4406 


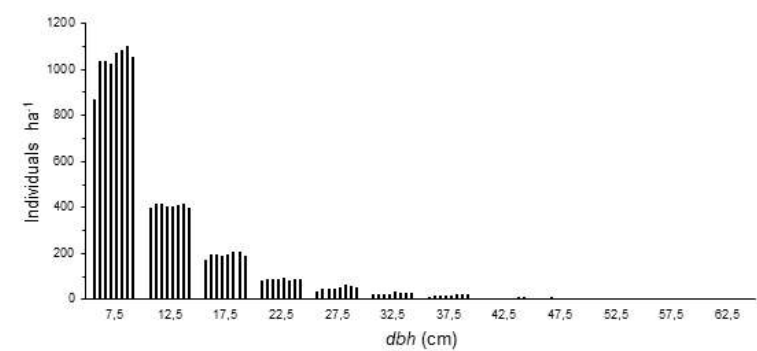

Figure 1 - Observed tree diameter distribution for the entire fragment from 1992 to 2016, in a southeast secondary Atlantic Forest, in Minas Gerais, Brazil (From left to right, in each diameter class, each bar corresponds to one inventory year in the sequence of $1992,1995, \ldots$, 2016)

Figura 1 - Distribuição de diâmetros observada, para o fragmento como um todo, de 1992 a 2016, em uma Mata Atlântica secundária do sudeste, em Minas Gerais, Brasil (Da esquerda para a direita, em cada classe de diâmetro, cada barra corresponde a um ano de inventário na sequência de 1992, 1995 , ..., 2016).

differed from the exponential model, which was reverse J-shaped. At site L01, no adherence to the reverse J-shaped model was evident in the years $1992(\mathrm{p}<0.001)$ and $1995(\mathrm{p}<0.010)$. In 1998 and 2001, the adherence was weak ( $p=0.128$ and $p=0.237$, respectively), but the diameter distribution began to reveal a reverse J-shaped from $2004(p=0.841)$. At site L08, there were differences between the observed and estimated diameter distributions in $1992(\mathrm{p}<0.05)$, and in the following inventory (1995) the reverse J-shaped was revealed ( $p$ $=0.400$ ). At site L10, up to the year 2004, the observed diameter distribution had not yet achieved the reverse J-shaped $(p<0.05)$, and the adherence of the estimated data to the observed findings remained low $(0.096 \leq \mathrm{p} \leq$ 0.183 ) after 2007.

On comparison of the variations in diameter distribution between 1992 (first measurement) and those of 2016 (last measurement), in a 24-year interval, the adherence between the observed and estimated distributions during this period was seen to rise. The diameter distribution moved towards the reverse $\mathrm{J}$-shaped as the forest increased in age, chiefly at the L01 and L08 (Figure 2). While this recovery appeared to be slow at the L10 (at the hilltop, and close to the border of the fragment), the reverse J-shaped was already being formed at the L09 (further into the forest fragment) since $1992(\mathrm{p}>0.237)$.

The $q$ increased considerably between 1992 and 2016 at the L01 (1.45 to 2.54), L02 (2.67 to 3.75), L08
(1.70 to 2.54), and L09 (1.93 to 4.38) sites. Conversely, the ratio value abruptly dropped at the sites L03 (3.28 to 2.30 ) and L05 (2.86 to 2.01), while only small variations were observed in the $\mathrm{q}$ ratio over time at the L04, L06, L07, and L10 sites. The $q$-value varied among different sites and over time (1.74 to 3.24), and showed disproportionality of the number of individuals among the diameter classes (0.14 to 11.00).

The estimated diameter distribution for the whole forest revealed small variations with the inventory years over the 24-year period, based on the identity test ( $p>0.05)$, except for the first inventory (1992), which showed differences when compared with the other inventory years $(\mathrm{p}<0.001)$, except in relation to 2007 . The diameter distribution varied considerably among the sites, showing different distributions for each site, within each inventory year (Figure 3 ). This dynamic in diameter varied over time. For instance, in 1992, the sites exerted a more intense effect on the diameter distribution and, through the years, the identity test detected a gradual rise in the similarity between the sites relative to the tree diameter distributions.

Despite observing the steady increase in the similarity among sites over time, it is apparent that the sites do not show the same diameter distribution and each one has its unique structural dynamics (Figure 4). For instance, site L10 showed no significant change over the 24 years. On the contrary, in the L01 site, the diameter distribution changed substantially, with a rise in the number of individuals in the smaller $d b h$ classes, as well as an escalation in the number of classes over the years. In general, the sites L02, L07, and L10 showed greater stability, whereas the sites L01, L08, and L09 revealed several changes in the diameter distribution over time.

\section{DISCUSSION}

The annual periodic increment of the quadratic mean diameter $\left(A P I_{D q}\right)$ over the 24-year time period was very low $\left(0.03 \mathrm{~cm}_{\text {year-1 }}\right)$, and is attributed to the balance between growth and mortality, as proposed by Condit et al. (1998) and Muller-Landau et al. (2006). High recruitment into the first diameter class is another plausible reason for this result. In the sites with the cumulative ingrowth, the $A P I_{D q}$ was negative, promoting a reduction in the average $A P I_{D q}$. This occurs because the $D q$ estimates consider the total number of individuals (n) in the denominator of the equation; thus,

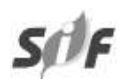

Revista Árvore 2020;44:e4406 

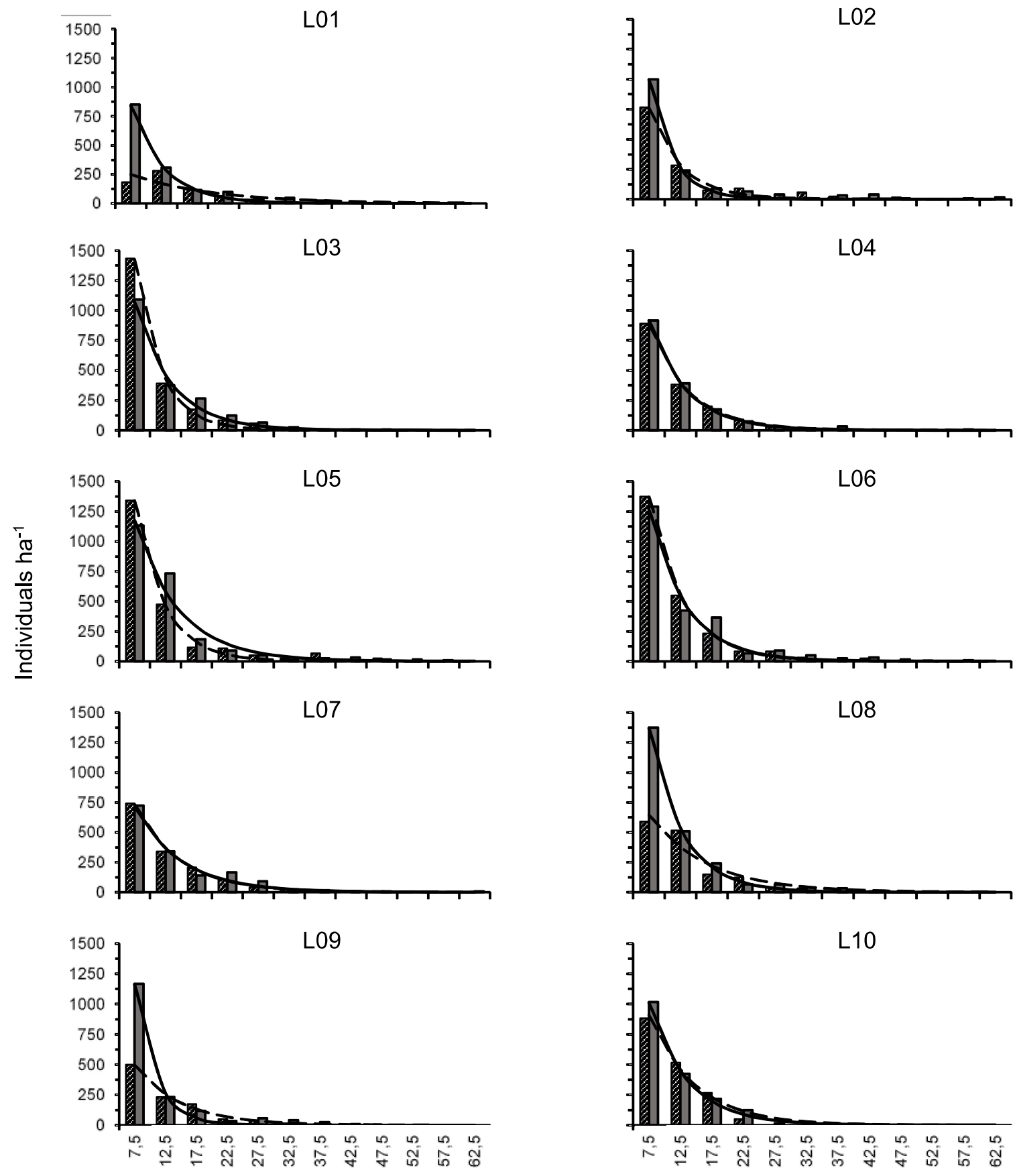

$d b h(\mathrm{~cm})$

Figure 2 - Observed and estimated tree diameter distribution in a southeast secondary Atlantic Forest, in Minas Gerais, Brazil (hatched bars - observed distribution of the first inventory; grey bars - observed distribution of the last inventory; dashed line - estimated distribution of the first inventory; solid line - estimated distribution of the last inventory)

Figura 2 - Distribuição de diâmetros, observada e estimada, em Mata Atlântica do sudeste, em Minas Gerais, Brasil (barras hachuradas - distribuição observada do primeiro inventário; barras cinzas - distribuiçấo observada do último inventário; linha tracejada distribuição estimada do primeiro inventário; linha sólida - distribuição estimada do último inventário)

Revista Árvore 2020;44:e4406 

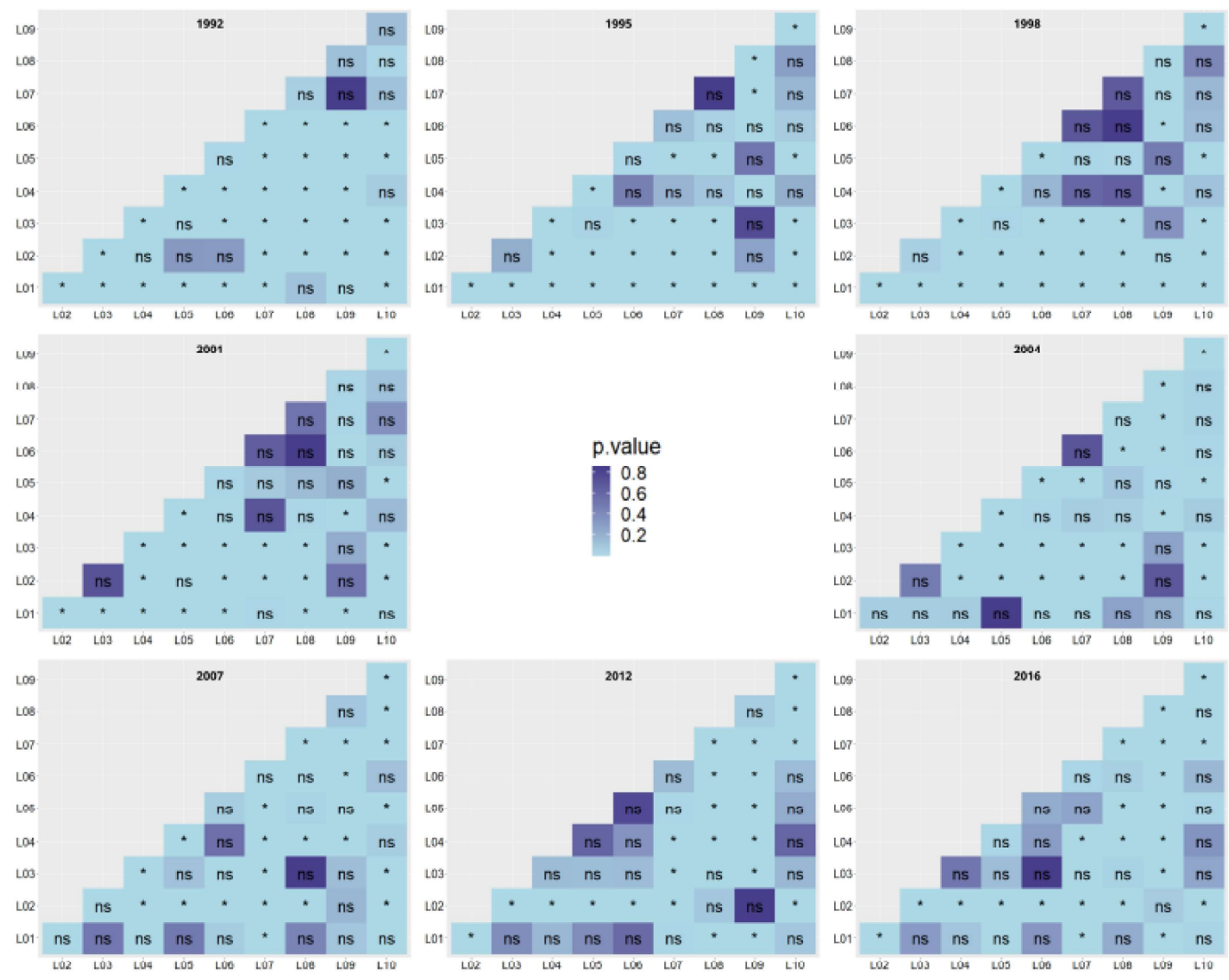

Figure 3 - Results of the identity tests of the tree diameter distributions, at different sites, for each inventory year (1992 to 2016), in a southeast secondary Atlantic Forest, in Minas Gerais, Brazil (ns = not significant at the 5\% probability level; * = significant). The increase in the intensity of the blue color indicates increasing $p$-value.

Figura 3 - Resultados dos testes de identidade das distribuições de diâmetro de árvores, em diferentes locais, para cada ano de inventário (1992 a 2016), em uma Mata Atlântica secundária do sudeste, em Minas Gerais, Brasil (ns = não significativo em nível de 5\% de probabilidade; *= significativo). O aumento na intensidade da cor azul indica aumento do valor de $p$.

several small individuals minimize the $D q$ estimates. However, the internal variations evident in the forest being investigated $\left(A P I_{D q}=-0.51\right.$ to $0.09 \mathrm{~cm} \mathrm{year}^{-1}$, taking all the inventory years and different sites into account), most likely resulted from the topographical and soil fertility differences in the conditions of the various sites (Caliman, 2015; Souza, 2015). According to Meyer (1952), variation in the curvature of the exponential function can result from changes in the number of individuals in the lower diameter classes than in the upper ones, tree migration to the upper classes, or upper-class tree mortality. The increased $D q$ observed value was a result of the rise in the rate of change of the individuals from the lower classes to the following classes, lowering the $\mathrm{q}$ value and curvature of the exponential function.
If the q quotient is less than the q-value of the population, there are problems with the diameter distribution (Smith and Lamson, 1982; Campos et al., 1983). By analyzing both the forest as a whole and the different sites, there were values above or below the $q$-value of the population when considering the forest as a whole or each specific site. For example, the values of $q$ quotient were much larger for L02, in 1992, and L08, in 2007, or much smaller for L01, in 1992, and L08, in 2007 , as compared to the $q$-value of the population.

By analyzing the behavior of the diameter distribution, when there is a gradual decrease in the number of individuals with increasing diameter classes, it is assumed that the forest presents low levels of disturbance, otherwise the forest has difficulty in establishing its structure (Carvalho and Nascimento,

Revista Árvore 2020;44:e4406 

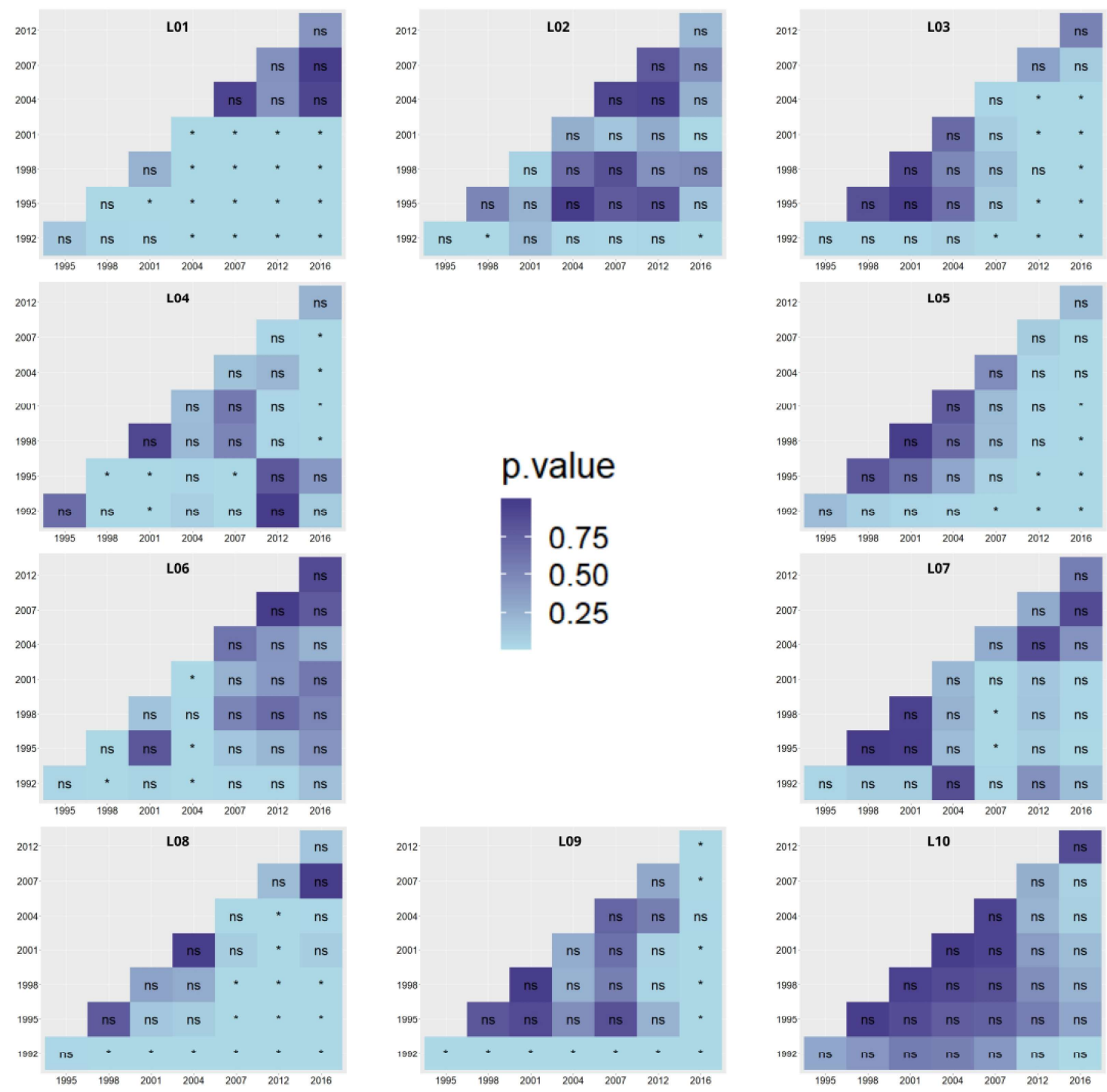

0.50
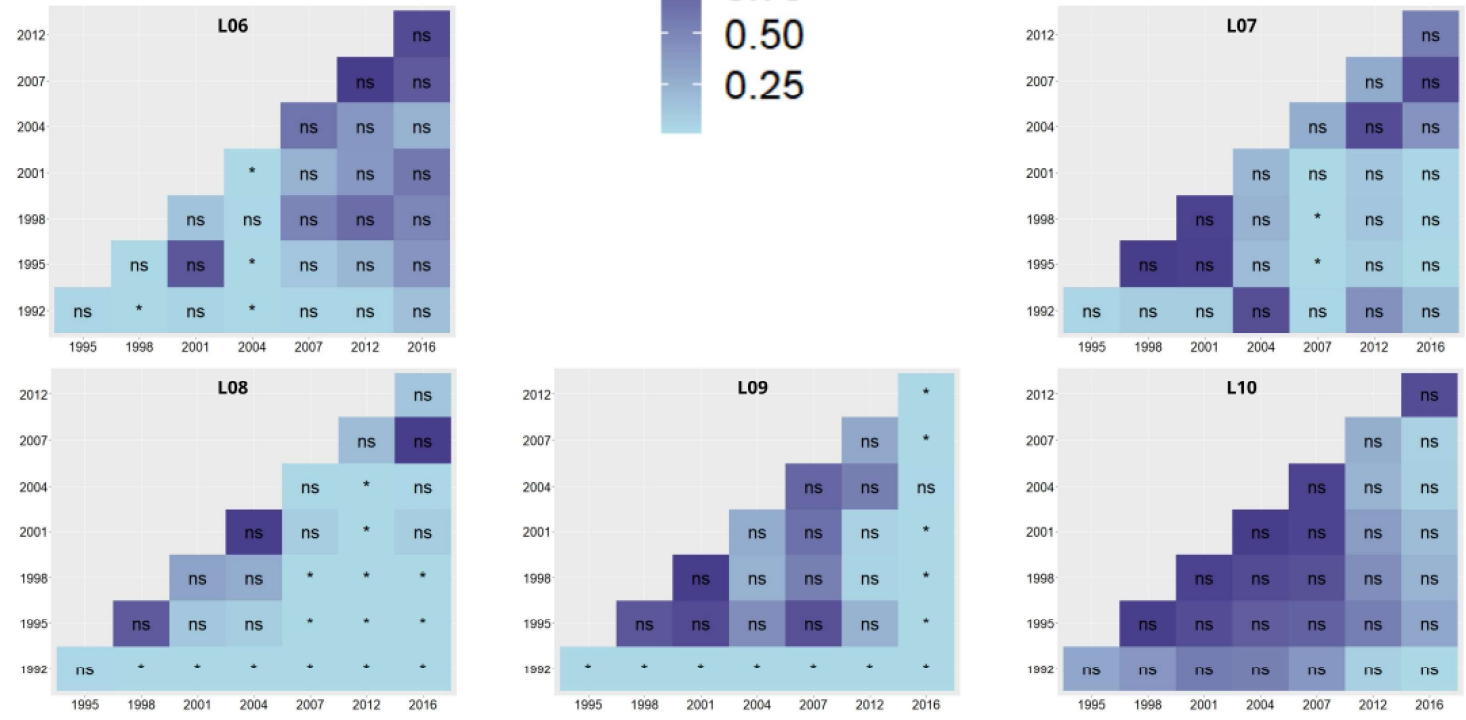

Figure 4 - Results of the identity tests of the tree diameter distribution, from 1992 to 2016 , for the different sites, in a secondary southeast Atlantic Forest, in Minas Gerais, Brazil (ns = not significant at the 5\% probability level; * = significant). The increase in the intensity of the blue color indicates increasing $p$-value.

Figura 4 - Resultados dos testes de identidade da distribuição de diâmetros, de 1992 a 2016, para os diferentes sítios, em uma Mata Atlântica secundária do sudeste, em Minas Gerais, Brasil ( $n s=$ não significativo em nivel de $5 \%$ de probabilidade; * = significativo). O aumento na intensidade da cor azul indica aumento do valor de $p$.

2009; Lima et al., 2013; Watzlawick et al., 2013; Reis et al., 2014). The analysis of the diameter distribution at the community level can be complemented by an analysis of populations or ecological groups (Carvalho and Nascimento, 2009; Lima et al., 2013; Reis et al., 2014), or by analysing specific sites, as performed in the present study, to better understand the structure of the forest.
Meyer's exponential function was able to give an accurate estimation of the distribution of forest tree diameters, as noted in other studies related to tropical forests (Campbell et al., 1992; Imaña-Encinas et al., 2013; Lima et al., 2015; Lima et al., 2017) and temperate forests (Westphal et al., 2006; Kucbel et al., 2012). By assuming that a community in equilibrium must demonstrate a reverse J-shaped diameter distribution

Revista Árvore 2020;44:e4406 
curve (Meyer, 1952), the study of this forest as a whole is balanced. The smallest $d b h$ class $(7.5 \mathrm{~cm})$ ensures the replacement of the mortality of the premature and old individuals because of the large number of individuals (on average, 1,036 individuals $\mathrm{ha}^{-1}$ ), representing, on average, $56.12 \%$ of the total individuals. Depending upon the diameter distribution, the young individuals appear to remain in the system, even with the effect exerted by the known anthropogenic action, which occurred before this study started.

The imbalance in the diameter distribution as the ratio $q$ varies in the number of trees sampled occurs in the successive diameter classes (Meyer, 1952). The Liocourt's Quotient regulates the distribution of the diameters curve shape enabling inferences regarding the recruitment and mortality in plant communities (Felfili et al., 1998). If the ratio $q$ among the classes is constant, the recruitment rate is similar to the mortality rate and the distribution is accepted as regular or balanced (Silva Júnior, 2004; Alves Junior et al., 2010).

The diameter distribution is widely used in sustainable forest management for controlling harvesting intensity (from the BDq method) allowing quantification of the cut intensity per hectare in number of trees, volume or basal area (Smith and Lamson, 1982; Campos et al., 1983; Campos and Leite, 2013; Souza and Soares, 2013). The main advantage of using the remaining basal area and the maximum diameter, associated with the $q$ quotient expressing the diameter distribution, is the application of a more rational selective harvesting technique, with a quantitative basis that ensures a continuous forest management (Campos et al., 1983; Campos and Leite, 2013; Souza and Soares, 2013). However, the degree of success in adopting this method is related to the correct decision on the values of the remaining basal area; of the maximum diameter to be reached; and frequency per diameter class per hectare, in addition to the right choice of trees to be removed in the partial harvesting (Campos et al., 1983).

The tree diameter distribution showed only slight variations indicating that results for the forest as a whole over the 24-year mask the variations that can be observed in different sites with distinct resilience capacities. Most studies on tropical forests include the analysis of plant diversity, regeneration processes, forest disturbance patterns, climate change interference, growth, biomass, and carbon production (Rolim et al., 2005; Chave et al., 2014; Alroy, 2017). Few studies have a bearing on the magnitude and temporal variability of the tree diameter distribution in the tropical forests (Felfili, 1997; Canalez et al., 2006; Machado et al., 2017).

The analysis of the diameter distribution at different sites and inventory years resulted in the identification of specific developmental characteristics. At sites L01, L08 and L10, the diameter distribution, in 1992, failed to follow the reverse J-shaped pattern probably due to past anthropogenic disturbances, such as selective logging and the presence of pasture in the neighbourhood (Garcia et al., 2011). Thus, over the 24-year period, these three sites showed the diameter distribution with adjustment to the reverse $\mathrm{J}$-shaped pattern as the forest did not experience any significant disturbances after this study started. From these findings, it is evident that the regeneration period, and the nature and intensity of the disturbances, can influence the diameter distribution. The low adherence of the estimated data to those recorded at the L10 site, even after 24 years, may be linked to its hilltop location, poor soil fertility and moisture, and likely intrusions from the neighboring areas (pasture area). The most stable diameter distribution was identified for the L03 and L04 sites, plausibly because they were in the vicinity of the spring bed of a watershed that had earlier been the major water source for the municipality, i.e., protected from the anthropic actions for a longer time.

There is a rise in the development of the number of long-term studies of sites experiencing different environmental conditions for temperate forests (Heiri et al., 2009; Vrška et al., 2009; Diaci et al., 2010; Kucbel et al., 2012) or boreal forests (Linder et al., 1997; Shorohova et al., 2009). This type of study shows the significance of investigating the diameter distribution of each tree species, the differences between the forests found in different environmental conditions, and the differences between the diverse environments in a forest, for the institution of management plans to ensure the right ways to exploit, protect or revitalize them.

According to Caliman (2015), these sites formed four groups based on floristic similarity (Jaccard) and three groups based on soil fertility. This variability may affect the diameter distribution, making it difficult to establish a standard response for the different sites in terms of diameter distribution. The sites L01, L02, L08, and L09, classified as medium fertility sites and, usually located on the hill slopes, presented a rapid rise in the $q$ value over time. The predominant species

\section{Revista Árvore 2020;44:e4406}


identified in these locations included P. gonoacantha, Senna multijuga (Rich.) H. S. Irwin \& Barneby, Siparuna guianensis Aubl., and Vernonia diffusa Less over the entire 24-year study period. The low and high fertility sites revealed no particular patterns in the tree diameter distribution dynamics, and the predominant species in the low fertility sites (L03, L04, L07, and L10) included: Apuleia leiocarpa (Vogel) J. F. Macbr., Eugenia cerasiflora Miq., Guapira opposita (Vell.) Reitz, Ladenbergia hexandra (Pohl) Klotzsch and S. guianensis. The high fertility sites (L05 and L06) showed the highest density of the Citronella paniculata (Mart.) R. A. Howard and G. opposita species. These two sites are in a later successional stage than the other sites as they are in the most preserved area.

The forest structure was adjusted even in the sites without reverse $\mathrm{J}$-shaped form, most likely because the forest had attained protected status and selective wood logging was prohibited. As this studied area is also partially surrounded by some forests of different successional stages, it possibly possessed a greater capacity for resilience in comparison to most of the small-sized $(<10$ ha) secondary Atlantic Forest fragments (SOSMA, 2016), reiterating the necessity to investigate the smaller and unprotected fragments.

\section{CONCLUSIONS}

Overall, the findings from this study reiterate that the analysis of the forest as a whole disallows the identification of the processes associated with the recovery capacity of the secondary forests. The tree diameter distribution of the whole forest showed the reverse J-shaped distribution over the 24-year period. However, it showed variations when taken into account the sites experiencing different physiographic and edaphic conditions, forest conservation level, and the neighborhood into which the forest is included. Variations were evident among the sites over this period in the recovery capacity of the reverse J-shaped distribution. Taking as a whole, the results indicate that, whenever possible, the management plan has to be sitespecific, particularly in the mountainous regions where more marked environmental variations exist.

\section{REFERENCES}

Arroyo-Rodríguez V, Melo FPL, Martínez-Ramos M, Bongers F, Chazdon RL, Meave JA et al. Multiple successional pathways in human-modified tropical landscapes: new insights from forest succession, forest fragmentation and landscape ecology research. Biological Reviews. 2017;92(1):326-340.

Alroy J. Effects of habitat disturbance on tropical forest biodiversity. Proc. Natl. Acad. Sci. USA. 2017;114(23):6056-6061.

Alves Junior FT, Ferreira RLC, Silva JAA, Marangon LC, Costa Junior RF, Silva SO. Use of the De Liocourt quotient in the evaluation of the diametric distribution in fragments of ombrophylous forest, Pernambuco State-Brazil. Ciência Forestal. 2010;20(2):307-319.

APG III. An update of the Angiosperm Phylogeny Group classification for the orders and families of flowering plants: APG III. Botanical Journal of the Linnean Society. 2009;161(2):105-121.

Caliman JP. Florística e distribuição vertical e horizontal de espécies arbóreas da Mata Atlântica, no Sudeste do Brasil. [dissertação]. Viçosa, MG : Universidade Federal de Viçosa; 2015.

Caliman JP. Estrutura diamétrica, biomassa, ingresso e mortalidade em Floresta Atlântica secundária ao longo de 24 anos. [tese]. Viçosa, MG : Universidade Federal de Viçosa; 2019.

Campbell DG, Stone JL, Rosas-Jr A. A comparison of the phytosociology and dynamics of three floodplain (Várzea) forests of known ages, Rio Juruá, western Brazilian Amazon. Botanical Journal of the Linnean Society. 1992;108(3):213-237.

Campos JCC, Leite HG. Mensuração florestal: perguntas e respostas. 5a. ed. atualizada e ampliada. Viçosa, MG: Ed. UFV; 2017. 636 p.

Campos JCC, Ribeiro JC, Couto L. Emprego da distribuição diamétrica na determinação da intensidade de corte em matas naturais submetidas ao sistema de seleção. Revista Árvore. 1983;7(2):110-122.

Canalez GG, Corte APD, Sanquetta CR. Structural dynamics of the lauraceae community during 1995 2004 in an Araucaria Forest, Southern Paraná State, Brazil. Ciência Florestal. 2006;16(4):357-367. 
Carvalho FA, Nascimento MT. Estrutura diamétrica da comunidade e das principais populações arbóreas de um remanescente de Floresta Atlântica Submontana (Silva Jardim-RJ, Brasil). Revista Árvore. 2009;33(2):327-337.

Chave J, Réjou-Méchain M, Búrquez A, Chidumayo E, Colgan MS, Delitti WBC, et al. Improved allometric models to estimate the aboveground biomass of tropical trees. Global Change Biology. 2014;20(10):3177-3190.

Denslow JS. Disturbance and diversity in tropical rain forests: the density effect. Ecol Appl. 1995;5(4):962968.

Diaci J, Rozenbergar D, Boncina A. Stand dynamics of dinaric old-growth forest in Slovenia: are indirect human influences relevant?. Plant Biosystems. 2010;144(1):194-201.

Felfili JM. Diameter and height distributions in a gallery forest tree community and some of its main species in central Brazil over a six-year period (19851991). Brazilian Journal of Botany. 1997;20(2):155162.

Felfili JM, Silva Júnior MC, Nogueira PE.

Levantamento da vegetação arbórea na região de Nova Xavantina, MT. Boletim do Herbário Ezechias Paulo Heringer. 1998;3:63-81.

Fernandes HAC. Dinâmica e distribuição de espécies arbóreas em uma floresta secundária no domínio da Mata Atlântica. [dissertação]. Viçosa, MG: Universidade Federal de Viçosa; 1998.

Garcia CC, Reis MGF, Reis GG, Pezzopane JEM, Lopes HNS, Ramos DC. Regeneração natural de espécies arbóreas em fragmento de Floresta Estacional Semidecidual Montana, no domínio da Mata Atlântica, em Viçosa, MG. Ciência Florestal. 2011;21(4):677-688.

Heiri C, Wolf A, Rohrer L, Bugmann H. Forty years of natural dynamics in Swiss beech forests: structure, composition, and the influence of former management. Ecological Applications. 2009;19(7):1920-1934.

Ige PO, Akinyemi GO, Abi EA. Diameter distribution models for tropical natural forest trees in Onigambari
Forest Reserve. Journal of Natural Sciences Research. 2013;3(12):14-22.

Imaña-Encinas José IE, Conceição CA, Santana OA, Imaña CR, Paula JE. Distribuição diamétrica de um fragmento de Floresta Atlântica no município de Santa Maria de Jetibá, ES. Revista Floresta. 2013;43(3):385394

Kucbel S, Saniga M, Jaloviar P, Vencurik J. Stand structure and temporal variability in old-growth beechdominated forests of the northwestern Carpathians: a 40-years perspective. Forest Ecology and Management. 2012;264:125-133.

Leite HG, Oliveira FHT. Statistical procedure to test identity between analytical methods. Commun Soil Sci Plant Anal. 2002;33(7-8):1105-1118.

Lima RAF, Batista JLF, Prado PI. Modeling tree diameter distributions in natural forests: an evaluation of 10 statistical models. Forest Science. 2015;61(2):320-327.

Lima RB, Aparicio PS, Silva WC, Silva DAS, Guedes ACL. Emprego da distribuição diamétrica na predição do estado de perturbação em florestas de várzea, Macapá-AP. Enciclopédia Biosfera. 2013;9(16):10161026.

Lima RB, Bufalino L, Alves Junior FT, Silva JAA, Ferreira RLC. Diameter distribution in a Brazilian tropical dry forest domain: predictions for the stand and species. Anais da Academia Brasileira de Ciências. 2017;89(2):1189-1203.

Linder P, Elfving B, Zackrisson O. Stand structure and successional trends in virgin boreal forest reserves in Sweden. Forest Ecology and Management. 1997;98(1):17-33.

Machado S, Cysneiros V, Nascimento RG, Martins A, Schmidt L. Projeção da estrutura diamétrica de grupos ecológicos em uma Floresta Ombrófila Mista. Floresta e Ambiente. 2017;24:e20160012.

Meyer HA. Structure, growth, and drain in balanced uneven-aged forests. Journal of Forestry.1952;50(2):85-92. 
Orellana E, Figueiredo Filho A, Péllico Netto S, Dias AN. Modelagem da distribuição diamétrica de espécies florestais em um fragmento de floresta ombrófila mista. Revista Árvore. 2014;38(2):297-308.

R CORE TEAM. R: A language and environment for statistical computing. Vienna, Austria : R Foundation for Statistical Computing; 2017.

Reis LP, Ruschel AR, Silva JNM, Reis PCM, Carvalho JOP, Soares MHM. Dinâmica da distribuição diamétrica de algumas espécies de Sapotaceae após exploração florestal na Amazônia Oriental. Revista de Ciências Agrárias - Amazon Journal of Agricultural and Environmental Sciences. 2014;57(3):234-243.

Reis LP, Souza AL, Reis PCMR, Mazzei L, Binoti DHB, Leite HG. Prognose da distribuição diamétrica na Amazônia utilizando redes neurais artificiais e autômatos celulares. Revista Floresta. 2018; 48(1):93102.

Rolim SG, Jesus RM, Nascimento HEM, Couto HTZ, Chambers JQ. Biomass change in an Atlantic tropical moist forest: the ENSO effect in permanent sample plots over a 22-year period. Oecologia. 2005;142:238246.

Schreuder HT, Swank WT. Coniferous stands characterized with the Weibull distribution. Canadian Journal of Forest Research. 1974;4(4):518-523.

Shorohova E, Kuuluvainen T, Kangur A, Jõgiste K. Natural stand structures, disturbance regimes and successional dynamics in the Eurasian boreal forests: a review with special reference to Russian studies. Annals of Forest Science. 2009;66:1-20.

Silva CT. Dinâmica da vegetação arbórea de uma floresta secundária no município de Viçosa, Minas Gerais. [dissertação]. Viçosa, MG: Universidade Federal de Viçosa; 2003.

Silva CT, Reis GG, Reis MGF, Silva E, Chaves RA. Avaliação temporal da florística arbórea de uma floresta secundária no município de Viçosa, Minas Gerais. Revista Árvore. 2004;28(3):429-441.

Silva Júnior MC. Phytosociology and diametric structure of Taquara gallery forest, at IBGE ecological reserve, DF. Revista Árvore. 2004;28(3):419-428.

Smith HC, Lamson NI. Number of residual trees: a guide for selection cutting. Northeastern Forest Experimental Station. Technical Report NE-80. USDA: Forest Service; 1982. 33p.

SOSMA - Fundação SOS Mata Atlântica. Relatório Anual; 2016. 130p.

Souza AL, Soares CPB. Determinação de cortes seletivos. In: Florestas Nativas: estrutura, dinâmica e manejo. Viçosa, MG: Ed. UFV; 2013. p.194-215.

Souza FC. Dinâmica da estrutura e do estoque de carbono da vegetação arbórea adulta em 20 anos, em floresta secundária da Mata Atlântica. [tese]. Viçosa, MG: Universidade Federal de Viçosa; 2015.

Souza LA, Matias HB, Binoti DHB, Leite HG, Mendonça AR, Silva GF, et al. Probability density functions for description of diameter distribution in thinned forest stands. Revista Brasileira de Biometria. 2016;34(3):421-434.

Torres CMME, Jacovine LAG, Soares CPB, Oliveira Neto SN, Santos RD, Castro Neto F. Quantifying biomass and carbon stock in a seasonal semideciduous forest in Viçosa, MG, Brazil. Revista Árvore. 2013;37(4):647-655.

Umaña CLA, Alencar JC. Distribuições diamétricas da Floresta Tropical úmida em uma área no município de Itacoatiara-AM. Acta Amazonica. 1998;28(2):167-190.

Vasconcelos SS, Higuchi N, D’Oliveira MVN. Projeção da distribuição diamétrica de uma floresta explorada seletivamente na Amazônia Ocidental. Acta Amazonica. 2009;39(1):71-80.

Vieira SA, Alves LF, Duarte-Neto PJ, Martins SC, Veiga LG, Scaranello MA, et al. Stocks of carbon and nitrogen and partitioning between above-and belowground pools in the Brazilian coastal Atlantic Forest elevation range. Ecology and Evolution. 2011;1(3):421-434.

Vrška T, Adam D, Hort L, Kolář T, Janík D. European beech (Fagus sylvatica L.) and silver fir (Abies alba Mill.) rotation in the Carpathians - A developmental

\section{Revista Árvore 2020;44:e4406}


cycle or a linear trend induced by man?. Forest Ecology and Management. 2009;258(4):347-356.

Westphal C, Tremer N, Von Oheimb G, Hansen J, Von Gadow K, Härdtle W. Is the reverse J-shaped diameter distribution universally applicable in European virgin beech forests?. Forest Ecology and Management.
2006;223(1-3):75-83.

Watzlawick LF, Gardin E, Longhi SJ, Andrade ECL. Estimate of the diameter distribution in Mixed Ombrophylous Forest fragment with the Meyer's function. Applied Research \& Agrotecnology. 2013;6(1):29-36.

\section{ERRATA}

No ARTIGo "TEMPORAL AND SPATIAL VARIABILITY OF THE DIAMETER DISTRIBUTION IN A SECONDARY BRAZILIAN ATLANTIC FOREST SUGGESTS SITE-SPECIFIC MANAGEMENT PRACTICES.”, PUblicado no volume 44, da REVISTa ÁrVore, onde SE Lê:

\footnotetext{
Jônio Pizzol Caliman²* ${ }^{2 *}$, Geraldo Gonçalves dos Reis ${ }^{3}$, Maria das Graças Ferreira Reis ${ }^{3}$, Hlio Garcia Leite $^{3}$,Carlos Moreira Miquelino Eleto Torres ${ }^{3}$, Margarete Marin Lordelo Volpato ${ }^{4}$, Rafael Tassinari Resende ${ }^{5}$ and Marco Antonio Monte ${ }^{6}$
}

L eia-s e:

Jônio Pizzol Caliman ${ }^{2 *}$, Geraldo Gonçalves dos Reis ${ }^{3}$, Maria das Graças Ferreira Reis ${ }^{3}$, Helio Garcia Leite ${ }^{3}$,Carlos Moreira Miquelino Eleto Torres ${ }^{3}$, Margarete Marin Lordelo Volpato ${ }^{4}$, Rafael Tassinari Resende ${ }^{5}$ and Marco Antonio Monte ${ }^{6}$ 